Wayne State University

\title{
DigitalCommons@WayneState
}

Department of Obstetrics and Gynecology

C.S. Mott Center for Human Growth and

Research Publications

Development

$1-1-1994$

\section{Expression and function of FGF-4 in peri- implantation development in mouse embryos}

Daniel A. Rappolee

Northwestern University, drappole@med.wayne.edu

Claudio Basilico

New York University

Yogesh Patel

Northwestern University

Zena Werb

University of California

\section{Recommended Citation}

Rappolee D. A., Basilico, C., Patel, Y., and Werb, Z. 1994. Expression and function of FGF-4 in peri-implantation development in mouse embryos. Development. 120, 2259-2269.

Available at: http://digitalcommons.wayne.edu/med_obgyn/4

This Article is brought to you for free and open access by the C.S. Mott Center for Human Growth and Development at DigitalCommons@WayneState. It has been accepted for inclusion in Department of Obstetrics and Gynecology Research Publications by an authorized administrator of DigitalCommons@WayneState. 


\title{
Expression and function of FGF-4 in peri-implantation development in mouse embryos
}

\author{
Daniel A. Rappolee ${ }^{1,2, *}$, Claudio Basilico ${ }^{3}$, Yogesh Patel ${ }^{2}$ and Zena Werb1 \\ ${ }^{1}$ Laboratory of Radiobiology and Environmental Health, University of California, San Francisco, CA 94143-0750, USA \\ ${ }^{2}$ Departments of Obstetrics and Gynecology and Cell, Molecular and Structural Biology, Northwestern University Medical School, \\ Chicago, IL 60611, USA \\ ${ }^{3}$ Department of Pathology, New York University, New York, NY 10016, USA \\ ${ }^{*}$ Author for correspondence at address ${ }^{2}$
}

\section{SUMMARY}

One of the earliest events in mammalian embryogenesis is the formation of the inner cell mass (ICM) and the subsequent delamination of primitive endoderm. We have found that mRNA for fibroblast growth factor (FGF)-4, but not FGF-3, is expressed in preimplantation mouse blastocysts and that the FGF-4 polypeptide is present in ICM cells. ICM-like embryonal carcinoma cells and embryonic stem cells also express FGF-4. Conversely, differentiated embryonal carcinoma cells in the endoderm lineage express FGF-3, but not FGF-4 mRNA.

Although mouse embryos expressed FGF-4 mRNA from the 1-cell stage, embryos cultured from the 2-cell through the blastocyst stage in the presence of recombinant FGF-4 did not respond mitogenically. However, when ICMs that were isolated by immunosurgery were cultured with FGF-
4, the number of morphologically distinct, differentiated parietal endoderm cells growing out onto the coverslip increased, without an increase in the number of undifferentiated ICM cells. ICM outgrowths cultured with FGF-4 increased their secretion of $92 \times 10^{3} M_{r}$ gelatinase and tissue plasminogen activator, a hallmark of migrating cells. Receptors for FGF-4 (FGFR-3 and FGFR-4) are expressed in all cells of the mouse blastocyst. These findings indicate that FGF-4 produced by undifferentiated ICM cells acts in the peri-implantation period of embryogenesis to influence the production and behavior of endoderm cells derived from them.

Key words: fibroblast growth factor, mouse embryogenesis, metalloproteinase, blastocyst, tissue plasminogen activator, RT-PCR

\section{INTRODUCTION}

Fibroblast growth factors (FGFs) are small polypeptides that mediate embryonic induction in vertebrates. FGFs are important mediators of mesoderm induction in Xenopus and chick and of limb development in mouse and chick (Rappolee and Werb, 1994; Niswander and Martin, 1992, 1993a,b; Vogel and Tickle, 1993). There are nine members of the FGF family (Hebert et al., 1990; Basilico and Moscatelli, 1992). In the present terminology, acidic FGF is FGF-1, basic FGF is FGF2, int-2 is FGF-3, Kaposi's sarcoma-type FGF is FGF-4 and keratinocyte growth factor is FGF-7; the other members are FGF-5, FGF-6, FGF-8 and FGF-9 (Basilico and Moscatelli, 1992; Tanaka et al., 1992; Miyamoto et al., 1993). Several members of the FGF family can induce mesoderm and markers for posterior mesoderm in animal cap preparations from Xenopus embryos (Kimelman and Kirschner, 1987; Ruiz i Altaba and Melton, 1989; Paterno et al., 1989). In whole frog embryos, overexpression of FGF induces anterior and posterior mesoderm (Kimelman and Maas, 1992). Expression of a dominant negative FGF receptor disrupts posterior/ventral mesoderm and the expression of brachyury in Xenopus (Amaya et al., 1991, 1993).
The role of FGF in early stages of mammalian development has not been well studied. Null mutants for FGF-3 have fewer vertebrae in the tail as well as other mutant phenotypes occurring later in development (Mansour et al., 1993). FGF-3, FGF-4 and FGF-5 are expressed at gastrulation (Hebert et al., 1990; Wilkinson et al., 1988; Niswander and Martin, 1992) in the day 7.0 post coitum (p.c.) mouse. At day 4.5 p.c., the inner cell mass (ICM) of the preimplantation mouse blastocyst contains FGF-4 mRNA (Niswander and Martin, 1992) but not FGF-2 (Rappolee et al., 1988). FGF-4 and FGF-3 are inversely regulated in embryonal carcinoma cells (Hebert et al., 1990; Velcich et al., 1989); that is, undifferentiated embryonal carcinoma stem cells express FGF-4 but not FGF-3, and differentiated cells (resembling parietal endoderm) express FGF3 but not FGF-4.

FGF action is mediated through the cooperative interaction of a high-affinity FGF receptor and a requisite low-affinity FGF receptor, such as the heparan sulfate proteoglycan syndecan protein (Klagsbrun and Baird, 1991). There are four members of the family of high-affinity receptors for FGF (Dionne et al., 1990; Lee et al., 1989; Keegan et al., 1991; Partanen et al., 1991, 1992; Johnson et al., 1991). Expression of high-affinity FGF receptors during mouse development has 
been investigated in postimplantation embryos but not in preimplantation embryos (Orr-Urtreger et al., 1991). FGF receptor (FGFR)-2 is expressed in the primitive ectoderm of day 5.5 p.c., and FGFR-1 is expressed in the primitive streak during gastrulation (Orr-Urtreger et al., 1991; Yamaguchi et al., 1992). Syndecan-1, a heparan sulfate proteoglycan, is expressed in mouse preimplantation and postimplantation embryos (Sutherland et al., 1991).

To define the role of FGF-4 in the earliest stages of mouse embryogenesis, we assayed the temporal expression of FGF-4 and FGF-3 mRNA in preimplantation mouse embryos. We also localized the FGF-4 polypeptide in ICM cells and determined some effects of FGF-4 expression at this stage of development. Transcripts for two of the four high-affinity FGF receptors were detected in all cells of the mouse blastocyst.

\section{MATERIALS AND METHODS}

\section{Materials}

Amplitaq DNA polymerase was purchased from Perkin-Elmer Cetus (Norwalk, CT). Restriction enzymes and T4 polynucleotide kinase were purchased from New England BioLabs (Beverly, MA) and Gibco/BRL (Gaithersburg, MD). Radioisotopes were obtained from New England Nuclear (Boston, MA). Moloney murine leukemia virus (MMLV) reverse transcriptase and Superscript MMLV reverse transcriptase were obtained from Gibco/BRL. Polymerase chain reaction (PCR) oligonucleotides were obtained from the University of California-San Francisco (UCSF) Biomolecular Resource Center or were synthesized in our laboratory on an Applied Biosystems PCR-Mate oligosynthesizer (Foster City, CA). Recombinant human FGF-4 and anti-FGF-4 polyclonal antibodies were produced as described by $\mathrm{C}$. Basilico in collaboration with Genetics Institute (Bellosta et al., 1993).

\section{Mouse eggs and embryos}

Standard techniques were used for obtaining eggs and zygotes (Hogan et al., 1986). Female CD-1 or CF-1 mice (6-10 weeks old, Charles River Laboratories, Wilmington, MA) were injected with 10 i.u. of pregnant mares' serum gonadotropin (Equitech, Kerrville, TX), followed by an injection of 5 i.u. of human chorionic gonadotropin (Serono, Randolph, MA) 44-48 hours later. After the second injection, females were housed overnight with $\mathrm{C} 57 \mathrm{BL} / 6 \mathrm{~J} \times \mathrm{SJL} / \mathrm{J} \mathrm{F}_{1}$ hybrid males (Jackson Laboratories, Bar Harbor, ME). Embryos were obtained at the following stages: 1-cell (12 hours p.c.), 2-cell (36 hours p.c.), 4-cell (48 hours p.c.), 8-cell (60 hours p.c.) and blastocyst (84-96 hours p.c.). 1-cell to 8-cell embryos were flushed from the oviducts of superovulated females and later embryos were dissected from the uteri of females (6.0, 7.5 or 8.5 days of gestation). Embryos were flushed from the uteri or oviducts of mice with flushing mediumI (FM-I) (Spindle, 1980) containing $3 \mathrm{mg} / \mathrm{ml}$ of bovine serum albumin. The embryos were then washed through 6 drops of FM-I. For isolation of ICMs, immunosurgery to remove trophectoderm was performed according to the method of Solter and Knowles (1975). All eggs and embryos were sorted and freed of debris under a dissecting microscope.

\section{RNA preparation}

A microadaptation (Rappolee et al., 1988, 1989) of the guanidine isothiocyanate ( $\mathrm{GuSCN})-\mathrm{CsCl}$ gradient ultracentrifugation technique was used to prepare total RNA from 100-200 embryos (Chirgwin et al., 1979). Embryos flushed from the genital tract at specific stages or cultured to specific stages were washed though 6 drops of FM-I, solubilized in $100 \mu \mathrm{l}$ of GuSCN containing $20 \mu \mathrm{g}$ of Escherichia coli rRNA (Boehringer Mannheim, Indianapolis, IN), layered over $100 \mu \mathrm{l}$ of $5.7 \mathrm{M} \mathrm{CsCl}$, and centrifuged for 2 hours at 80,000 revs/minute in a TL-100A rotor in a Beckman TL-100 benchtop ultracentrifuge. Yields of RNA were based on carrier amount and ranged from $35 \%$ to $80 \%$. RNA used for positive controls was isolated from P388D1 macrophages or from retinoic acid-treated F9 teratocarcinoma cells, as described previously (Rappolee et al., 1988; Brenner et al., 1989). The concentration of RNA was determined by measurement of absorbance at $260 \mathrm{~nm}$.

\section{Reverse transcription-polymerase chain reaction (RT- PCR)}

RT-PCR was performed essentially as described previously (Rappolee et al., 1988, 1989, 1992; Hahnel et al., 1990) with the use of the oligonucleotide primers shown in Table 1. Briefly, RNA was reverse-transcribed with 100 units of MMLV reverse transcriptase or Superscript MMLV reverse transcriptase primed with $0.2 \mu \mathrm{g}$ of random hexanucleotides (Pharmacia, Piscataway, N.J.) or $0.5 \mu \mathrm{g}$ of 12- to 18-mer oligo(dT) (Bethesda Research Laboratories) in a $20 \mu \mathrm{l}$ mixture. In early studies on FGF expression, reaction mixtures were heat-denatured and flash-cooled; 50 additional units of buffered Superscript MMLV was added and the reaction mixture was reincubated. The proportion of the reaction mixture that was equivalent to 10 embryos was added to sequence-specific primed PCR reaction

Table 1. Oligonucleotide primers used for RT-PCR

\begin{tabular}{|c|c|c|c|c|}
\hline Gene & $\begin{array}{l}\text { Primer sequences } \\
\text { (position in sequence) }\end{array}$ & $\begin{array}{l}\text { Amplified } \\
\text { length } \\
\text { (bp) }\end{array}$ & $\begin{array}{l}\text { RT-PCR } \\
\text { threshold } \\
\text { RNA source }\end{array}$ & $\begin{array}{l}\text { Diagnostic } \\
\text { restriction } \\
\text { enzyme }\end{array}$ \\
\hline $\begin{array}{l}\text { FGF-3 }{ }^{\mathrm{a}} \\
\text { FGF-3 }\end{array}$ & $\begin{array}{l}\text { 5' GTGCGGCTGCTGCAGAGTAGCCA } \\
\text { 3' CTGGAGTTGGTCTCAGAGGGCTT } \\
\left(5^{\prime}, 5887-5909 ; 3^{\prime}, 6078-6090\right)\end{array}$ & 204 & $\begin{array}{l}10 \mathrm{pg} \\
\mathrm{F} 9 \\
\text { differentiated }\end{array}$ & BalI \\
\hline $\begin{array}{l}\text { FGF-4b } \\
\text { FGF-4 }\end{array}$ & $\begin{array}{l}\text { 5' CCGGTGCAGCGAGGCGTGGT } \\
\text { 3' GGAAGGAAGTGGGTGACCTTCAT } \\
\left(5^{\prime}, 958-977 ; 3^{\prime}, 1618-1640\right)\end{array}$ & 255 & $\begin{array}{l}10 \mathrm{pg}, \\
\text { F9 } \\
\text { undifferentiated }\end{array}$ & HaeIII \\
\hline $\begin{array}{l}\mathrm{LIF}^{\mathrm{c}} \\
\mathrm{LIF}\end{array}$ & 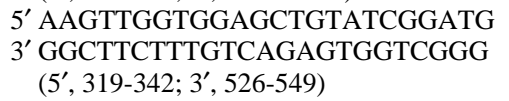 & 236 & $\begin{array}{l}10 \mathrm{pg}, \\
\text { P388D1 }\end{array}$ & SmaI \\
\hline $\begin{array}{l}\text { Brachyuryd } \\
\text { Brachyury }\end{array}$ & $\begin{array}{l}5^{\prime} \text { CTAGCCAGTATCCCAGTCTCTGG } \\
3^{\prime} \text { GACTGTAGCCCCTTCATACAT } \\
\left(5^{\prime}, 1139-1161 ; 3^{\prime}, 1312-1336\right)\end{array}$ & 198 & $\begin{array}{l}100 \mathrm{pg} \\
7.5 \mathrm{dg} \\
\text { embryo }\end{array}$ & SmaI \\
\hline $\begin{array}{l}\text { Actine }^{\mathrm{e}} \\
\text { Actin }\end{array}$ & $\begin{array}{l}5^{\prime} \text { CGTGGGCCGCTCTAGGCACCA } \\
3^{\prime} \text { TTGGCCTTAGGGTTCAGGGGGG } \\
\left(5^{\prime}, 23-43 ; 3^{\prime}, 245-266\right)\end{array}$ & 243 & $\begin{array}{l}10 \mathrm{pg}, \\
\mathrm{Balb} / \mathrm{c} 3 \mathrm{~T} 3\end{array}$ & $B g l I I$ \\
\hline
\end{tabular}


mixture in a buffer containing $10 \mathrm{mM}$ Tris- $\mathrm{HCl}(\mathrm{pH} \mathrm{8.3),} 600 \mu \mathrm{M}$ each dNTP, $5 \mu \mathrm{M}$ trimethyl ammonium chloride (Sigma Chemical Co., St. Louis, $\mathrm{MO}$ ), and $4.0 \mathrm{mM} \mathrm{MgCl} 2$ in a 50 litre reaction mixture (Rappolee et al., 1988). $2 \mu \mathrm{m}$ of embryonic stem cell or F9 teratocarcinoma cell RNA was reverse-transcribed, and one tenth of the reaction mixture (or a 10-fold dilution series of it) was amplified by PCR. The mixture was overlaid with $100 \mu \mathrm{l}$ of mineral oil and amplified for 60 cycles on a Perkin-Elmer Cetus Thermocycler programmable heating block. The PCR fragments were separated on a $4 \%$ agarose gel (3\% GTG/1\% Seakem, FMC Corp., Rockland, ME) and visualized by ethidium bromide staining. Gels were photographed with a Polaroid MP-4 camera and negative images were reversed for clarity of presentation. Fragments were verified by size and restriction enzyme mapping (Brenner et al., 1989). For restriction enzyme analysis, the fragments were precipitated with ammonium acetate directly from the PCR reaction mixture, washed twice with $70 \%$ ethanol and digested according to the restriction enzyme manufacturer's instructions.

\section{Embryo culture}

For each analysis, 30-40 embryos were cultured from the 2-cell to the blastocyst stage in CZB medium (Chatot et al., 1989) or in TE medium at 10 embryos per $20 \mu 1$ drop (Spindle, 1980) under paraffin oil (Aldrich, Milwaukee, WI). ICMs were isolated from expanded blastocysts (4.5 day p.c.) by immunosurgery (Solter and Knowles, 1975) and cultured on glass or on coverslips coated with fibronectin. For determination of cell number in embryos, ICMs were cultured for 3 days with or without FGF-4. For assay of metalloproteinases, ICMs were cultured for 3 days with $10^{-8}$ M FGF-4. All experiments were performed at least twice.

\section{Cell culture}

Embryonal carcinoma F9 cells, obtained from the UCSF Cell Culture Facility, were cultured on gelatin (Sigma)-coated culture dishes in Dulbecco's modified Eagle's medium containing $10 \%$ heat-inactivated fetal bovine serum. D3 embryonic stem cells (Alexander and Werb, 1992) were cultured on $0.1 \%$ gelatin-coated dishes as described by Robertson (1987). For collection of conditioned medium for sodium dodecyl sulfate (SDS)-substrate gel analysis, the confluent cell cultures were incubated in serum-free medium for 24 hours. Medium conditioned by rabbit synovial fibroblasts stimulated to secrete proteinases was obtained as described previously (Unemori and Werb, 1988).

\section{Endoderm differentiation of embryonal carcinoma and embryonic stem cells}

Undifferentiated F9 teratocarcinoma cells $\left(5 \times 10^{5}\right)$, which resemble undifferentiated ICM cells, were seeded onto gelatin-coated $10-\mathrm{cm}$ tissue culture dishes and cultured for up to 6 days with or without $5 \times 10^{-7} \mathrm{M}$ retinoic acid, $10^{-4} \mathrm{M}$ or $10^{-3} \mathrm{M}$ dibutyryl cAMP, and 5 $\mathrm{mM}$ isobutylmethylxanthine in Dulbecco's modified Eagle's medium containing 10\% calf serum (Strickland et al., 1980; Solter et al., 1979; Hogan et al., 1986). We used this procedure to obtain cells that resemble the parietal endoderm, which are progeny cells of the primitive endoderm (Strickland et al., 1980; Hogan et al., 1986). Embryonic stem cells were differentiated to endoderm by removal of leukemia inhibitory factor (LIF), aggregation, and readherence as described previously (Robertson, 1987).

\section{Indirect immunocytochemistry and nuclear staining}

For immunocytochemical analysis, blastocysts were either fixed in solution without centrifugation or centrifuged onto poly-L-lysinecoated coverslips in a Shandon (White Plains, NY) cytocentrifuge at $900 \mathrm{revs} / \mathrm{minute}$ for 30 minutes and fixed in $2 \%$ paraformaldehyde ( $\mathrm{pH}$ 7.2) in phosphate-buffered saline. The blastocysts were stained with rabbit polyclonal anti-human FGF-4 antibody (diluted at 1:200). For specificity controls, $0.5 \mu \mathrm{g}$ of diluted anti-human FGF-4 antibody was absorbed with human FGF-4. The primary antibody was followed by staining with biotinylated anti-rabbit IgG and then by Texas Redlabeled streptavidin as described previously (Rappolee et al., 1988). Alternatively, streptavidin-alkaline phosphatase was used on whole unattached blastocysts as described above, but all fixation and permeabilization steps were performed in solution. This was done to maintain morphology of the blastocyst to identify the cells expressing FGF-4 antigen. An insoluble product was developed by using bromo-chloro-indolyl phosphate and nitroblue tetrazolium (Vector, Burlingame, CA). Embryos fixed and stained in solution were viewed in rectangular microcapillary tubes (Vitro Dynamics, Passaic, NJ). All photography was performed with a Zeiss Photomicroscope III and water immersion $25 \times$ or $63 \times$ phase Plan-Neofluor lenses, and Tri-X film was exposed and developed under similar lighting conditions.

To determine the response of embryos to FGF, FGF-4 was serially diluted in $100 \mu \mathrm{l}$ volumes and added at appropriate concentrations with 20 2-cell embryos in $20 \mu 1$ droplets under oil and cultured for 3 days; blastocysts were then fixed onto glass coverslips and stained.

For staining of nuclei, embryos were fixed in solution by $3: 1$ ( $\mathrm{vol} / \mathrm{vol}$ ) ethanol-glacial acetic acid on coverslips and incubated in 1 $\mu \mathrm{g} / \mathrm{ml}$ of Hoechst 33258 in water for 5 minutes and destained overnight (Handyside and Hunter, 1984). Nuclei were counted and photographed as described above.

\section{Zymography of proteinases on SDS-substrate gels}

To determine whether extracellular matrix-degrading proteinases were secreted during mouse embryogenesis, immunosurgically isolated ICMs were cultured for 24-72 hours in T+2xAA medium (Spindle, 1980) or RPMI medium containing lactalbumin hydrolysate in the presence or absence of $10^{-8}$ M FGF- 4 . The conditioned medium was then analyzed by zymography, as described previously (Unemori and Werb, 1988). Briefly, conditioned medium (5-20 $\mu \mathrm{l})$ was diluted with $4 \times$ SDS sample buffer without 2-mercaptoethanol and then loaded onto $10 \%$ or $12 \%$ SDS-polyacrylamide gels containing $1 \mathrm{mg} / \mathrm{ml}$ of either gelatin or casein and $10 \mu \mathrm{g} / \mathrm{ml}$ human plasminogen, as described previously (Brenner et al., 1989; Behrendtsen et al., 1992). After electrophoresis the gels were washed 2 times for 15 minutes each time in $2.5 \%$ Triton X-100 (Sigma) and incubated for 24 to 48 hours at $37^{\circ} \mathrm{C}$ in $350 \mathrm{mM}$ Tris- $\mathrm{HCl}$ buffer (pH 7.6) containing $10 \mathrm{mM} \mathrm{CaCl}_{2}$. Gels were then stained in Coomassie Blue R250, followed by destaining. Clear bands indicate the presence of proteinases. For quantification of proteinases, negatives of gels were scanned with a Pharmacia scanning densitometer and peaks were plotted with the Cricket graph program on a Macintosh IIsi computer.

\section{In situ hybridization}

Amplimers of FGFR-1-4 receptors and syndecan-1 (Rappolee et al., unpublished data) were cloned into PcrII vectors according to the manufacturer's protocols (Invitrogen). The identity of the amplimer was verified by restriction analysis at two diagnostic sites, and some were sequenced (Rappolee et al., 1988). Amplimers for FGFR-4, FGFR-3, and syndecan-1 were derived from sequences in the $3^{\prime}$ untranslated region. Digoxigenin cRNA was prepared from plasmid DNA and treated with RNase-free DNase to remove the template (Genius RNA labeling kit, Boehringer-Mannheim).

Blastocysts were processed according to methods described below. After collection, blastocysts were reinjected (within 30 minutes of recovery from the uterus) into the oviduct for sectioning (Chapman and Wolgemuth, 1993). For sectioning, the oviducts were fixed in $4 \%$ paraformaldehyde buffered in neutral PBS overnight, dehydrated and embedded in paraffin, and three $10 \mu \mathrm{m}$ sections were made. After dehydration the slides were air-dried and stored at $-20^{\circ} \mathrm{C}$ until use.

In situ hybridization was performed according to a modified protocol of Harkey et al. (1992) (Rappolee et al. unpublished data). Paraffin sections were dewaxed, rinsed in $100 \%$ ethanol and air dried. Sections were rehydrated, washed in PBS containing $0.1 \%$ Tween 20 
(PBT) and treated with proteinase $\mathrm{K}(20 \mathrm{mg} / \mathrm{ml}$ in PBT). The proteinase $K$ was neutralized in glycine in PBS, washed with PBT, refixed with $4 \%$ paraformaldehyde in PBS and washed in PBT. The slides were prehybridized at $60^{\circ} \mathrm{C}$ for 1 hour. Prehybridization solution was removed and $10 \mu \mathrm{l}$ of hybridization solution containing $100 \mathrm{ng}$ of digoxigenin-labeled RNA probe was added; the slide was hybridized at $50^{\circ} \mathrm{C}$ in a humidified box overnight. All labeled probes had a sensitivity of 20-100 fM by dot-blot hybridization. After hybridization the slides were washed at $50^{\circ} \mathrm{C}$ in $50 \%$ PBT-50\% prehybridization solution in PBT at $50^{\circ} \mathrm{C}, 1 \times \mathrm{SSC}$ at $60^{\circ} \mathrm{C}$ in PBT and incubated with PBT containing $2 \%$ normal sheep serum to block nonspecific binding. Slides were incubated with 1:2000 dilution of antidigoxigenin-Ap conjugate in PBT-1\% normal sheep serum and washed in PBT and alkaline phosphatase buffer including levamisole for 5 minutes. The color reaction was carried out until sufficient product was visible. The reaction was stopped with PBT, slides were stained with Hoechst $33258(10 \mu \mathrm{g} / \mathrm{ml}$ in water $)$, destained, dehydrated and mounted in medium (Tris-EDTA with $\mathrm{NaN}_{3}$ ), and the coverslips were sealed with rubber cement (Harkey et al., 1992; Rappolee et al., unpublished data). Photomicrography was done with a Nikon Microphot-FXA microscope (Melville, NY). Micrographs were taken with epifluorescence to detect Hoechst-stained nuclei (with a barrier filter at $420 \mathrm{~nm}$ ) or diascopic illumination to see color products, using Kodak 200 DIN print film. Objectives were chosen to cover the field for pertinent detail at $100 \times$ and $200 \times$ (Nikon Plan 10 and Plan 20 objectives, respectively). series of whole RNA from undifferentiated F9 cells (Fig. 1A). In contrast, FGF-3 mRNA was not detected in preimplantation mouse embryos, although it was detected by day 6 p.c.

Table 2. Expression of mRNA for FGF-4 and FGF-3 during $F 9$ cell differentiation

\begin{tabular}{lrcccccc}
\hline \multicolumn{7}{c}{ PCR products visualized during F9 cell differentiation state } \\
\cline { 2 - 8 } & mRNA & & & & & & \\
assayed & F9 stem & 4d RA & 4d RA & 4d RA & 4d RA & \\
(ng) & cells & 1d cAMP & 2d cAMP & 3d cAMP & 4d cAMP & 4d RA \\
\hline Actin & 200 & + & + & + & + & + & + \\
& 20 & + & + & + & + & + & + \\
& 2 & + & + & + & + & + & + \\
FGF-3 & 200 & - & + & + & + & + & + \\
& 20 & - & + & + & + & + & + \\
& 2 & - & + & + & + & - & - \\
FGF-4 & 200 & + & - & - & + & + & + \\
& 20 & + & - & - & - & - & - \\
& 2 & + & - & - & - & - & -
\end{tabular}

F9 teratocarcinoma cells were cultured alone or with retinoic acid (RA) and cAMP as described in the text. '+' indicates expression and '-' indicates lack of expression of PCR products as visualized by ethidium bromide staining. $d$, days.

\section{Statistical analysis \\ The mean increase in cell number of mouse embryos cultured with FGF-4 was compared with that of control embryos by Student's $t$ - test on a Macintosh computer with software from Glantz (1992).}

\section{RESULTS}

\section{FGF-4 mRNA expression in preimplantation mouse embryos}

RT-PCR was performed on 1-cell, 2cell, 8-cell and blastocyst-stage mouse embryos for analysis of mRNA. FGF-4 was first detected at the 1-cell stage and increased in accumulation through the blastocyst stage. After implantation, FGF-4 mRNA was expressed in 6- and 8.5-day mouse embryos. RT-PCR detected FGF-4 in as little as $10 \mathrm{pg}$ of RNA in a dilution

\section{\begin{tabular}{ccc|cc|c|c}
1 & 2 & 8 & 64 & 6 & 8.5 & $M$
\end{tabular} Dilution of + control}

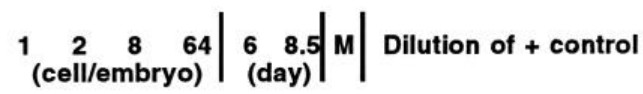
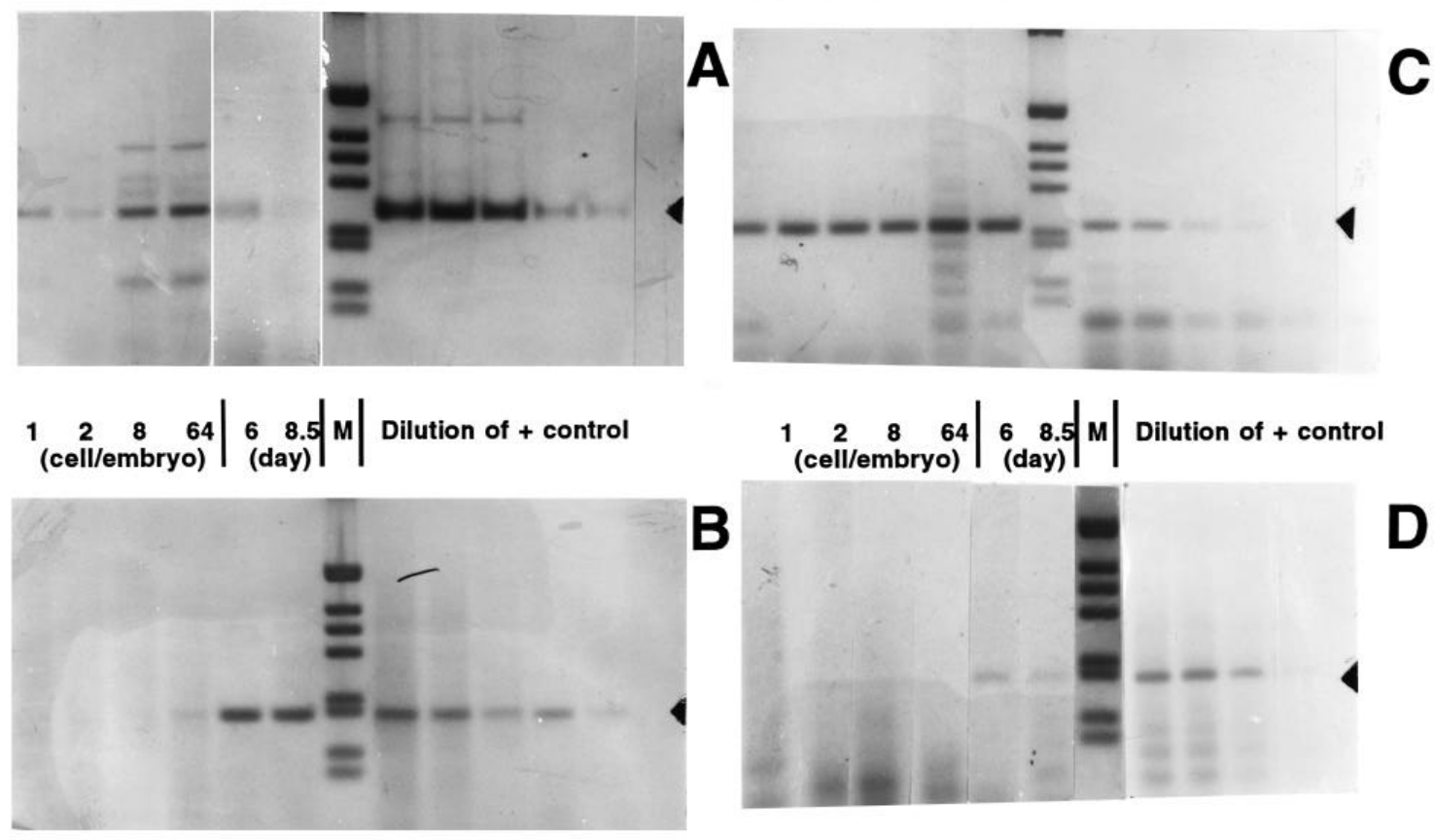

Fig. 1. FGF-4 mRNA is expressed from the 1-cell through the blastocyst stage. RNA from 100 embryos at each stage was purified by a microadaptation of the $\mathrm{GuSCN} / \mathrm{CsCl}$ technique, a first-strand synthesis of cDNA was made, and one tenth of the mixture was amplified for 60 cycles in the PCR. Growth factors were detected in PCR fragments by agarose gel electrophoresis. (A) FGF-4, (B) FGF-3, (C) LIF, (D) brachyury. Each lane of preimplantation embryos represents the equivalent of 10 embryos. Day 6 p.c. represents a single embryo, and day 8.5 p.c. represents 0.25 embryo. M, molecular weight standards (1 kb ladder, BRL). Control RNA is shown in a series of 10-fold dilutions beginning at the left with $100 \mathrm{ng}$ of whole RNA. The sources of control RNA are (A) undifferentiated F9 cells, (B) differentiated parietal endoderm-like F9 cells, (C) P388D1 macrophages, and (D) day 7.5 mouse embryos. Arrowheads indicate RT-PCR products of the following sizes: (A) $253 \mathrm{bp}$, (B) $204 \mathrm{bp}$, (C) 236 $\mathrm{bp}$, and (D) $178 \mathrm{bp}$. 
and continued to be expressed through day 8.5, and FGF-3 mRNA was detected in 10 pg of RNA from F9 cells differentiated to parietal endoderm (Fig. 1B). These data extend previous observations in which FGF-4 mRNA was detected as early as the blastocyst stage (Niswander and Martin, 1992) and FGF-3 polypeptide was detected in gastrulation-stage (day 7 p.c.) embryos (Wilkinson et al., 1988). As a positive control for the expression of a growth factor, we also determined the expression of mRNA for LIF, previously reported in preimplantation mouse embryos (Murray et al., 1990; Conquet and Brulet, 1990). LIF mRNA was expressed at all stages of preimplantation mouse development (Fig. 1C). Brachyury, a T locus gene associated with the initial induction of mesoderm (Wilkinson et al., 1990; Herrmann et al., 1990), was not detected before implantation but was detected in day 6 p.c. embryos (Fig. 1D), before overt mesoderm differentiation (Tam and Beddington, 1987).

FGF-4 mRNA was expressed in undifferentiated F9 teratocarcinoma stem cells, as previously reported (Velcich et al., 1989; Hebert et al., 1990) but was not detected in the immediate endodermal progeny of these cells; however, FGF4 mRNA was expressed again after continued culture of the differentiated cells (Table 2). FGF-3 mRNA was expressed only after differentiation of stem cells into parietal endoderm cells induced by retinoic acid and dibutyryl cAMP.

\section{FGF-4 polypeptide expression in ICM cells}

Mouse blastocysts that had been attached to poly-L-lysine-coated coverslips by cytocentrifugation or fixed in solution were analyzed immunocytochemically with a polyclonal antibody to human FGF-4, which cross-reacts with mouse FGF-4. FGF-4 polypeptide was detected in ICM cells but not in trophectoderm of mouse blastocysts by immunocytochemistry (Fig. 2A,B,F). After preincubation of the antiFGF-4 antibody with excess recombinant FGF4 , FGF-4 was no longer detected in ICM cells (Fig. 2C,D). These data corroborate a previous report of localized FGF mRNA in mouse ICM cells (Niswander and Martin, 1992).

\section{Effects of exogenous FGF-4 on cultured preimplantation embryos}

To determine if FGF-4 affects the growth rate of preimplantation embryos, we cultured 2-cell embryos through the blastocyst stage in medium alone or with recombinant FGF-4 $\left(4.3 \times 10^{-12}-4.3 \times 10^{-7} \mathrm{M}\right)$ in a 10 -fold dilution series. In duplicate experiments, there was no significant effect on cell number at the late blastocyst stage (Fig. 3; $P>0.05$; Student's $t$ test). This lack of responsiveness of preimplantation embryos to exogenous FGF-4 was paralleled by a lack of effect when endogenous FGF-4 was reduced in 2-cell to blastocyststage embryos by antisense FGF-4 oligonucleotides (data not shown), even though antisense insulin-like growth factor (IGF)-II inhibits growth in the same culture system (Rappolee et al., 1992).

\section{Effect of exogenous FGF-4 on proliferation of ICM- derived cells}

Because FGF-4 was concentrated in the ICM, we next looked for effects on ICM-derived cells. ICMs were isolated by removal of the trophectoderm of late-stage (day 4.5 p.c.) blastocysts, then cultured on glass or on fibronectin-coated dishes with or without FGF-4 $\left(8.7 \times 10^{-10} \mathrm{M}\right)$. The total number of adherent ICM-derived cells was increased by FGF-4 after 3 days of culture in serum-free medium on glass (Fig. 4A). The increase was confined to outgrowing cells with medium-sized nuclei that morphologically resembled parietal endoderm and that stained with parietal endoderm markers such as SPARC and laminin, but not SSEA-1 (O. Behrendtsen et al., unpublished data). The number of cells with small whorled nuclei, morphologically resembling ICM cells, was not affected by FGF-4 (Fig. 4A). Isolated ICMs cultured in serum-free medium on fibronectin-coated dishes showed a time-dependent increase in the number of outgrowing cells when stimulated by FGF-4 (Fig. 4B). The greatest increase occurred on the last day
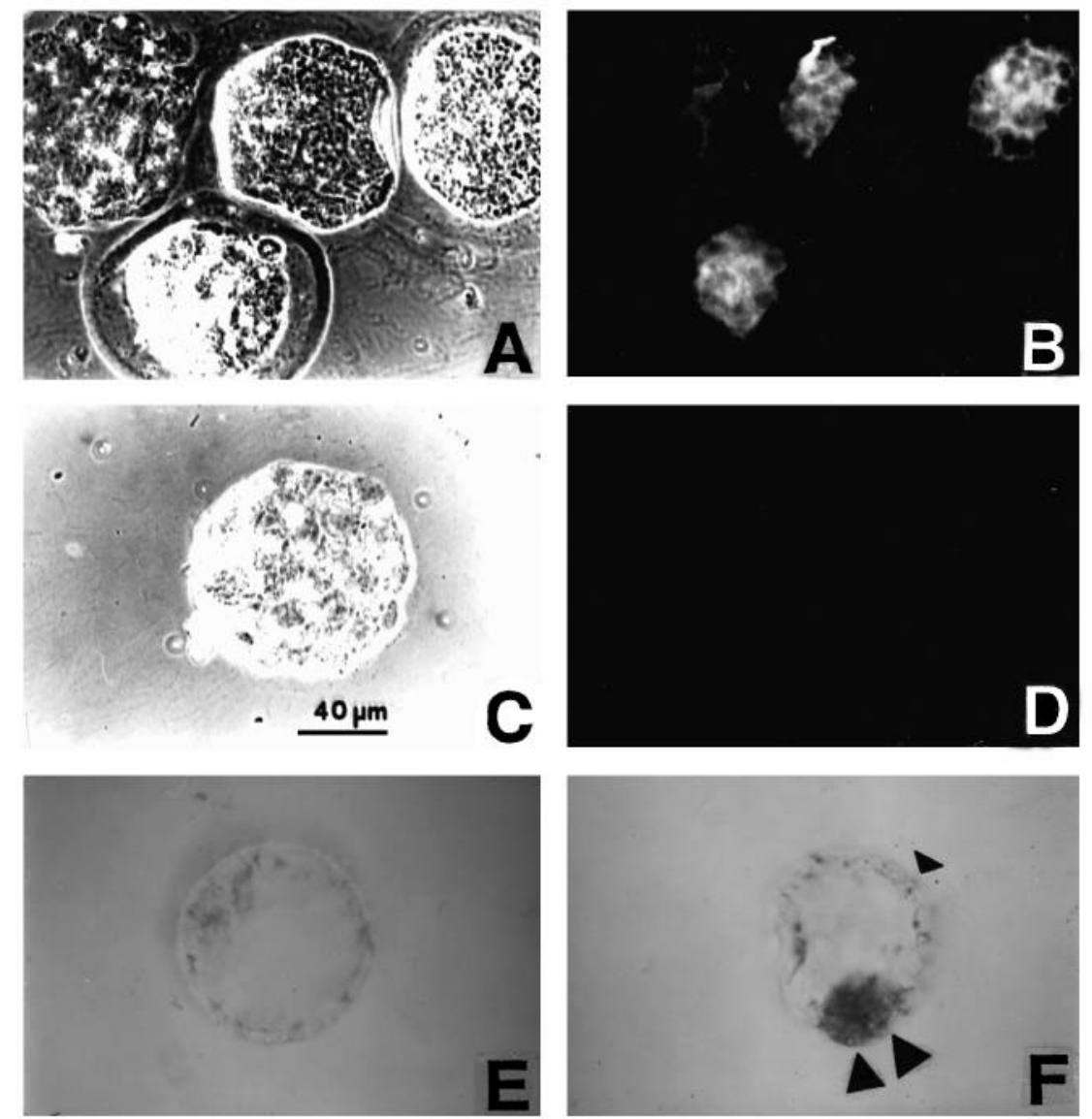

Fig. 2. FGF-4 polypeptide is expressed in the ICM of the mouse blastocyst. Mouse embryos were grown in vitro, centrifuged and fixed onto coverslips, and stained for FGF-4 in the presence (D) or absence (B) of excess FGF-4 ligand. (C,A) Corresponding phase photomicrographs of the indirect immunofluorescence shown in D and B, respectively. Whole-mount blastocysts were fixed and stained with normal rabbit serum (E) or FGF-4 antiserum (F) and developed by means of indirect alkaline phosphatase chemistry. Large arrowheads indicate FGF-4 staining in the ICM, and small arrowheads indicate nonspecific staining at junctional complexes in the trophectoderm. 


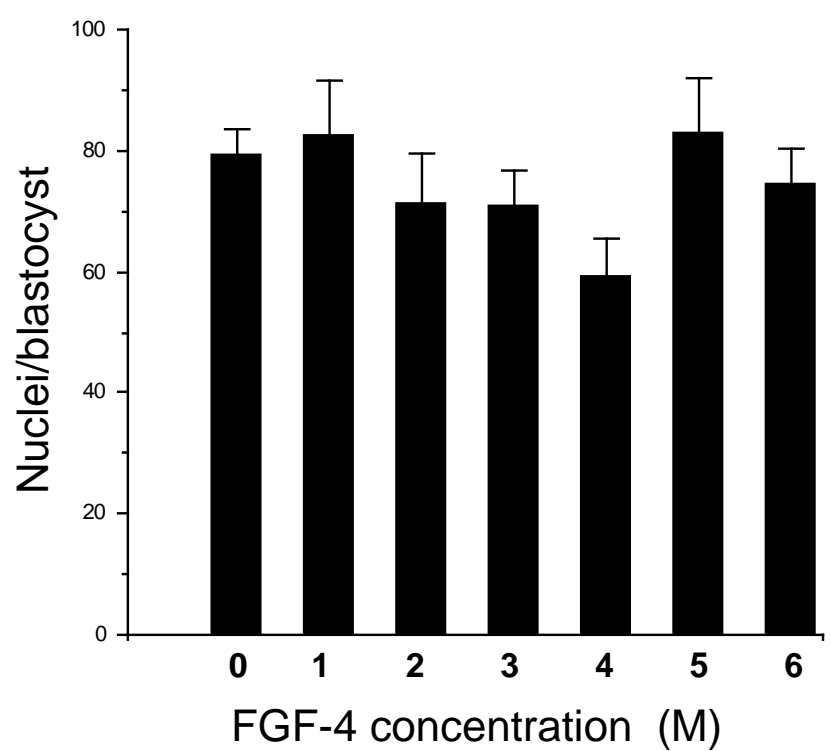

Fig. 3. FGF-4 does not stimulate growth in mouse embryos cultured from the 2-cell through the blastocyst stage. 2-cell embryos were cultured in medium alone or with a range of FGF-4 concentrations: 0 (medium alone), $1,4.3 \times 10^{-12} \mathrm{M} ; 2,4.3 \times 10^{-11} \mathrm{M} ; 3,4.3 \times 10^{-10} \mathrm{M} ; 4$, $4.3 \times 10^{-9} \mathrm{M} ; 5,4.3 \times 10^{-8} \mathrm{M} ; 6,4.3 \times 10^{-7} \mathrm{M}$. Embryos were fixed onto coverslips and stained with Hoechst 33258 , and nuclei were counted. Bars indicate s.e.m.

of culture; the number of outgrowing cells with medium-sized nuclei on day 3 (Fig. 4B) was about 4-fold greater than the number of cells with medium-sized nuclei growing out from FGF-stimulated ICMs cultured on glass (Fig. 4A). Because the ICMs were isolated from late-stage blastocysts, no trophectoderm cells were formed (Hogan and Tilly, 1978; Handyside, 1978). Thus, outgrowing ICM cells, mostly parietal endoderm and/or primitive endoderm, appear to be the targets of FGF-4.

\section{Effect of FGF-4 on secretion of $92 \mathrm{kDa}$ gelatinase and plasminogen activators by ICM cells}

Increases in the secretion of the metalloproteinase $92 \mathrm{kDa}$ $\left(M_{\mathrm{r}}=92 \times 10^{3}\right)$ gelatinase and of plasminogen activators are a hallmark of endoderm differentiation (Adler et al., 1990). Because FGF-4 appeared to stimulate differentiation of ICM to parietal endoderm, we analyzed the effect of FGF-4 on secretion of $92 \mathrm{kDa}$ gelatinase and plasminogen activators by assaying the conditioned medium by SDS-polyacrylamide substrate gel zymography (Brenner et al., 1989). ICMs in groups of 10 were cultured with or without $8.7 \times 10^{-10} \mathrm{M}$ FGF4 for 24 hours. As a positive control, ICMs were cultured with retinoic acid $\left(10^{-7} \mathrm{M}\right)$, a known stimulator of endoderm differentiation (Adler et al., 1990). A 4-fold increase in secretion of $92 \mathrm{kDa}$ gelatinase $(P<0.002$; Student's $t$-test $)$ was observed after a 24-hour incubation of ICMs with FGF-4 or retinoic acid (Fig. 5A,B). When ICMs were incubated with both FGF-4 and retinoic acid, the two behaved additively and a significant increase was seen over ICMs treated with FGF-4 or retinoic acid alone $(P<0.001$ and $P<0.002$, respectively) (Fig. 5A,B). FGF-4 also increased expression of tissue plasminogen activator in ICM cells (Fig. 5C), indicating that FGF-4 stimulates parietal endoderm differentiation (Marotti et al., 1982; Imada et al., 1990).

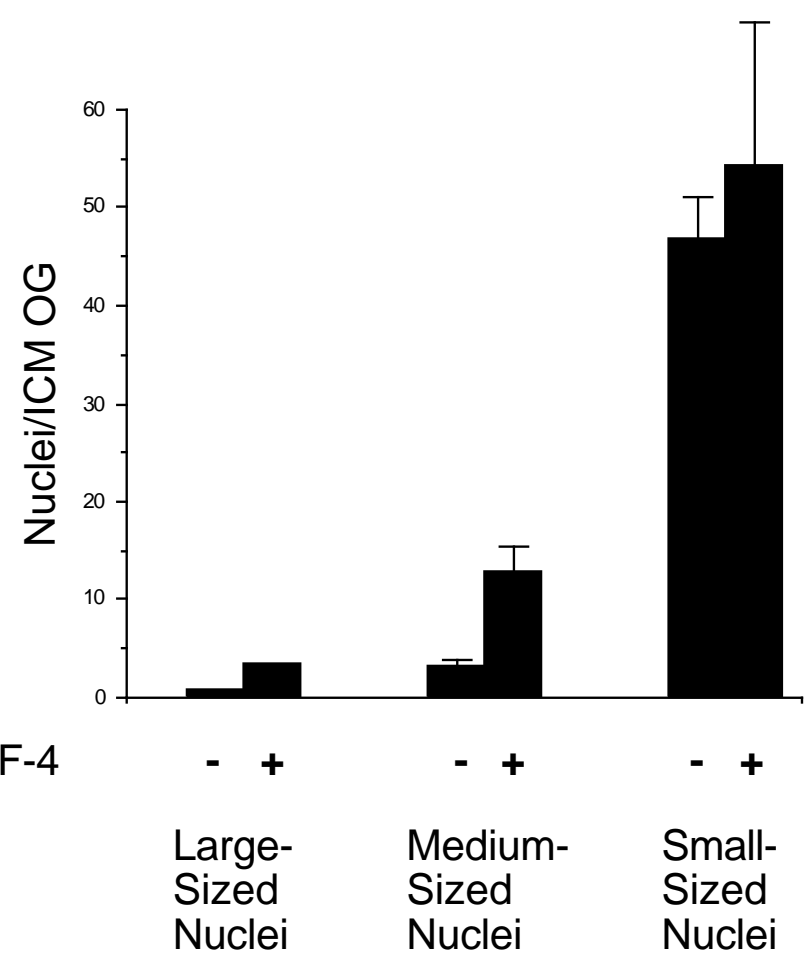

A

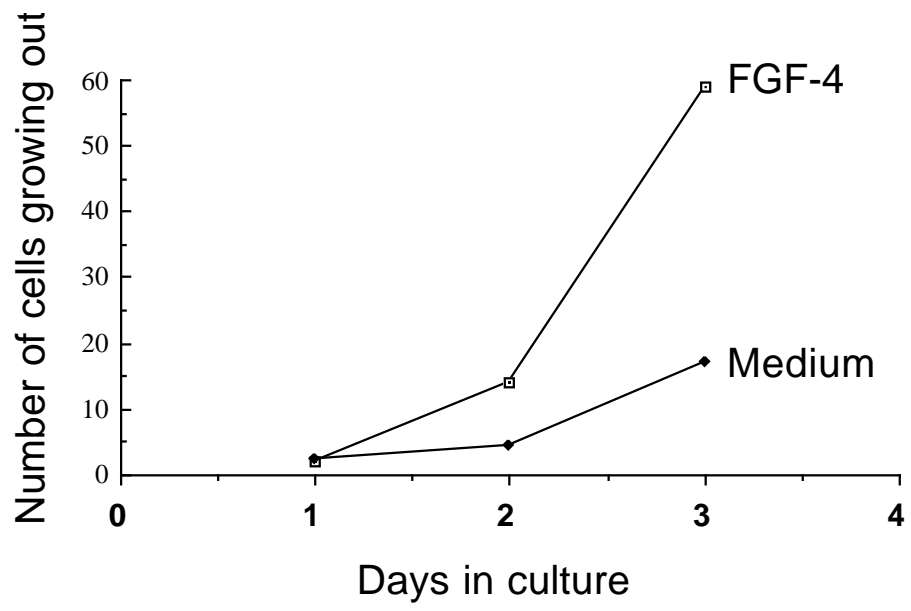

\section{B}

Fig. 4. FGF-4 stimulates ICMs to increase the number of outgrowing cells with medium-sized nuclei. ICMs were isolated from blastocysts by immunosurgery. Briefly, blastocysts were incubated with antimouse serum, washed, and exposed to complement. Outer trophectoderm cells were lysed, and the ICMs were cultured for 3 days with or without $8.7 \times 10^{-10}$ M FGF-4 on glass (A) or fibronectin (B). (A) Embryonic cells were fixed and stained with Hoechst 33258, and all sizes of nuclei were counted. (B) Embryonic cells were fixed and stained, and nuclei were counted as in (A) after 1, 2, and 3 days of culture. In this assay only cells with medium-sized nuclei (parietal endoderm-like) were counted. Bars indicate s.e.m.

\section{Expression of FGFR-3 and FGFR-4 mRNA in the blastocyst}

To determine if receptors for FGF-4 were present, we 
examined blastocysts by in situ hybridization. FGFR-4 mRNA was detected in every cell of the 3.5-day blastocyst (Fig. 6A,C). FGFR-3 mRNA was also expressed in every cell of the
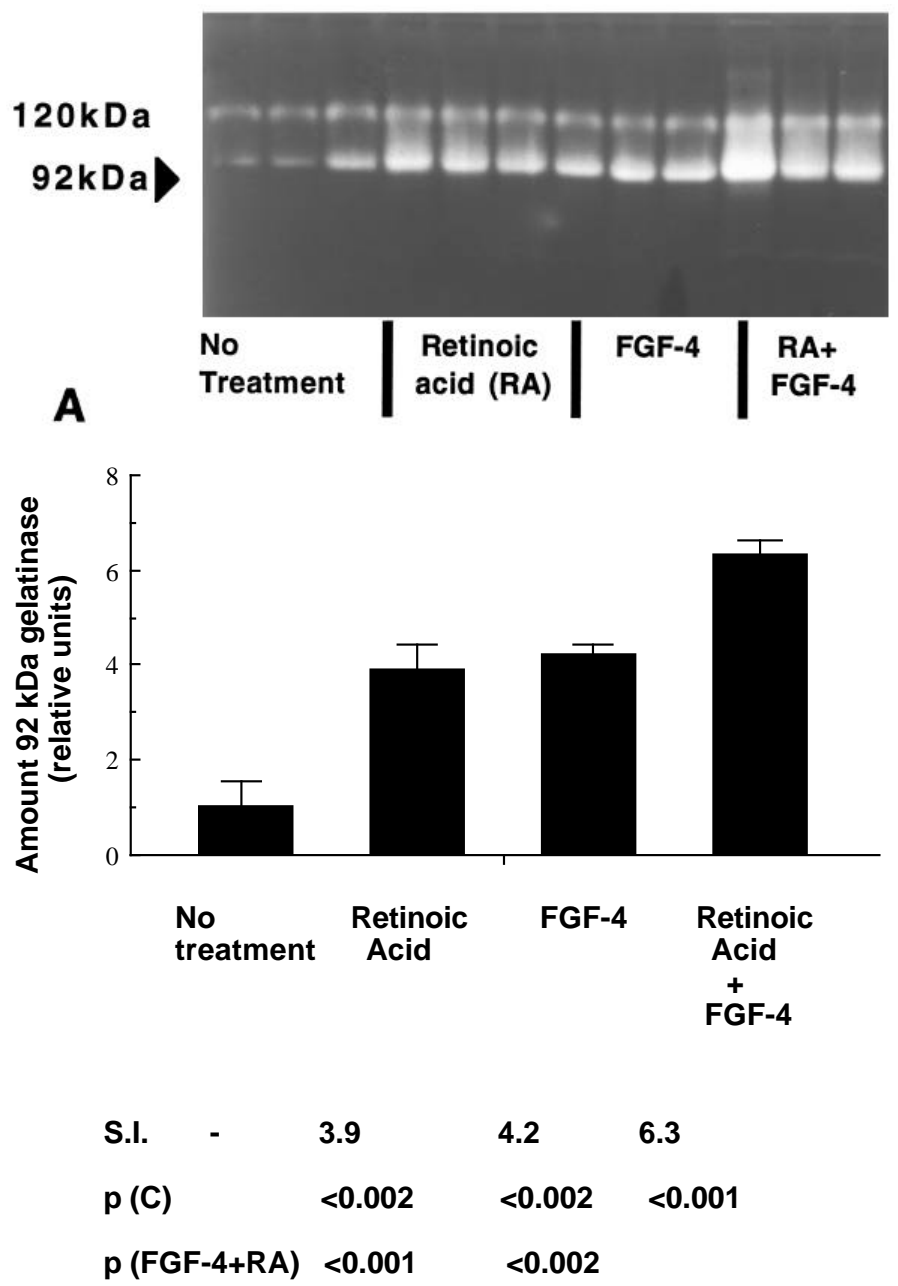

B

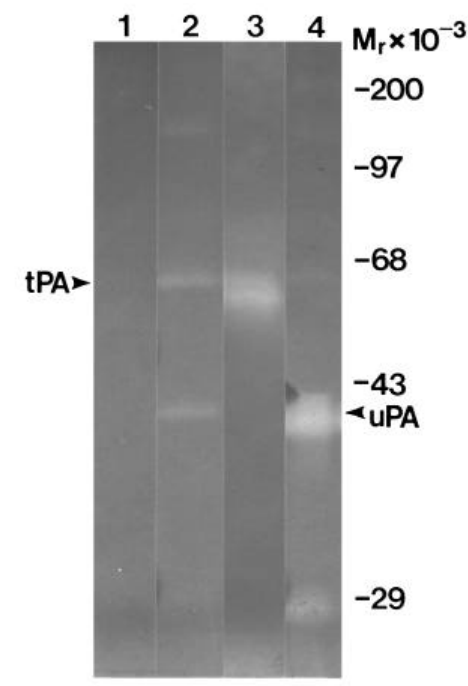

C blastocyst, but the expression was less intense than that of FGFR-4 and was greater in the trophectoderm than in the ICM. FGFR-1 and -2 were expressed at background levels (data not shown).

\section{DISCUSSION}

Our data show that FGF-4 and FGF-3 mRNA are expressed in peri-implantation embryos but that only FGF-4 mRNA is expressed before implantation. FGF-4 mRNA was found at all stages of preimplantation mouse embryos from 1-cell through blastocyst, whereas FGF-3 mRNA was not found before implantation. FGF-4 mRNA was found as a maternal transcript, appeared to decrease at the 2-cell stage and was strongly expressed at the blastocyst stage. FGF-4 mRNA decreases and FGF-3 mRNA increases immediately after stimulation of differentiation of embryonal carcinoma cells by retinoic acid (Velcich et al., 1989; Hebert et al., 1990). We observed that the expression of FGF-4 polypeptide was limited to the ICM cells in the blastocyst, in agreement with the expression pattern of FGF-4 mRNA (Niswander and Martin, 1992).

Seventeen growth factors are expressed in mouse preimplantation embryos, and 15 other growth factors are not expressed (Rappolee and Werb, 1994). The temporal expression pattern of FGF-4 mRNA resembles that of transforming growth factor (TGF)- $\alpha$ and of PDGF-A chain, which are expressed as maternal transcripts and as zygotic transcripts at the blastocyst stage (Rappolee et al., 1988). LIF mRNA is expressed throughout preimplantation development, whereas TGF- $\beta$ and IGF-II are expressed only after the 2-cell stage (Rappolee et al., 1988, 1992). Unlike IGF-II, TGF- $\alpha$ and PDGF-A chain polypeptides, which are expressed in every cell of the mouse blastocyst (Rappolee et al., 1988, 1992), FGF-4 is expressed only in the ICM. Attenuation of endogenous IGF-II results in a decrease in total cell number in the cultured blastocyst, without a clear effect on any subpopulation of cells (Rappolee et al., 1992). Because FGF-4 and the TGF- $\beta$ family members activin and TGF- $\beta 2$ are expressed in subsets of cells in the blastocyst (Rappolee and Werb, 1994), these growth factors may mediate signaling between cells in the blastocyst.

Fig. 5. FGF-4 stimulates ICM cells to increase their secretion of 92 $\mathrm{kDa}$ gelatinase and plasminogen activator. (A) FGF-4 induces secretion of metalloproteinases by ICM outgrowths as detected by zymography on SDS-polyacrylamide gelatin gels. (B) Retinoic acid $\left(10^{-7} \mathrm{M}\right)$ or FGF-4 $\left(8.7 \times 10^{-10} \mathrm{M}\right)$ stimulates an approximate 4 -fold increase in $92 \mathrm{kDa}$ collagenase, and FGF-4 and retinoic acid together stimulate an approximate 6 -fold increase in $92 \mathrm{kDa}$ collagenase in outgrowing progeny of ICM cells (S.I.=stimulation index). The differences between ICM outgrowths treated with one or two stimuli were significant in relation to the control (no treatment) and to each other. (C) FGF-4 induces secretion of plasminogen activators by ICM outgrowths. ICMs were plated singly on spots coated with 20 $\mu \mathrm{g} / \mathrm{ml}$ fibronectin in $5 \mu \mathrm{l}$ drops of serum-free medium in the absence (lane 1) or presence (lane 2) of $10^{-8}$ M FGF-4. The conditioned medium was collected after 3 days, and $9 \mu$ (from 2 ICMs) was separated on SDS-polyacrylamide casein-plasminogen gels. The zymogram was incubated at $37^{\circ} \mathrm{C}$ for 52 hours. Standards were Bowes melanoma tissue plasminogen activator (tPA, 0. $01 \mathrm{U}$; lane 3) and low molecular weight urokinase (uPA; lane 4) from mouse trophoblast cultures. 

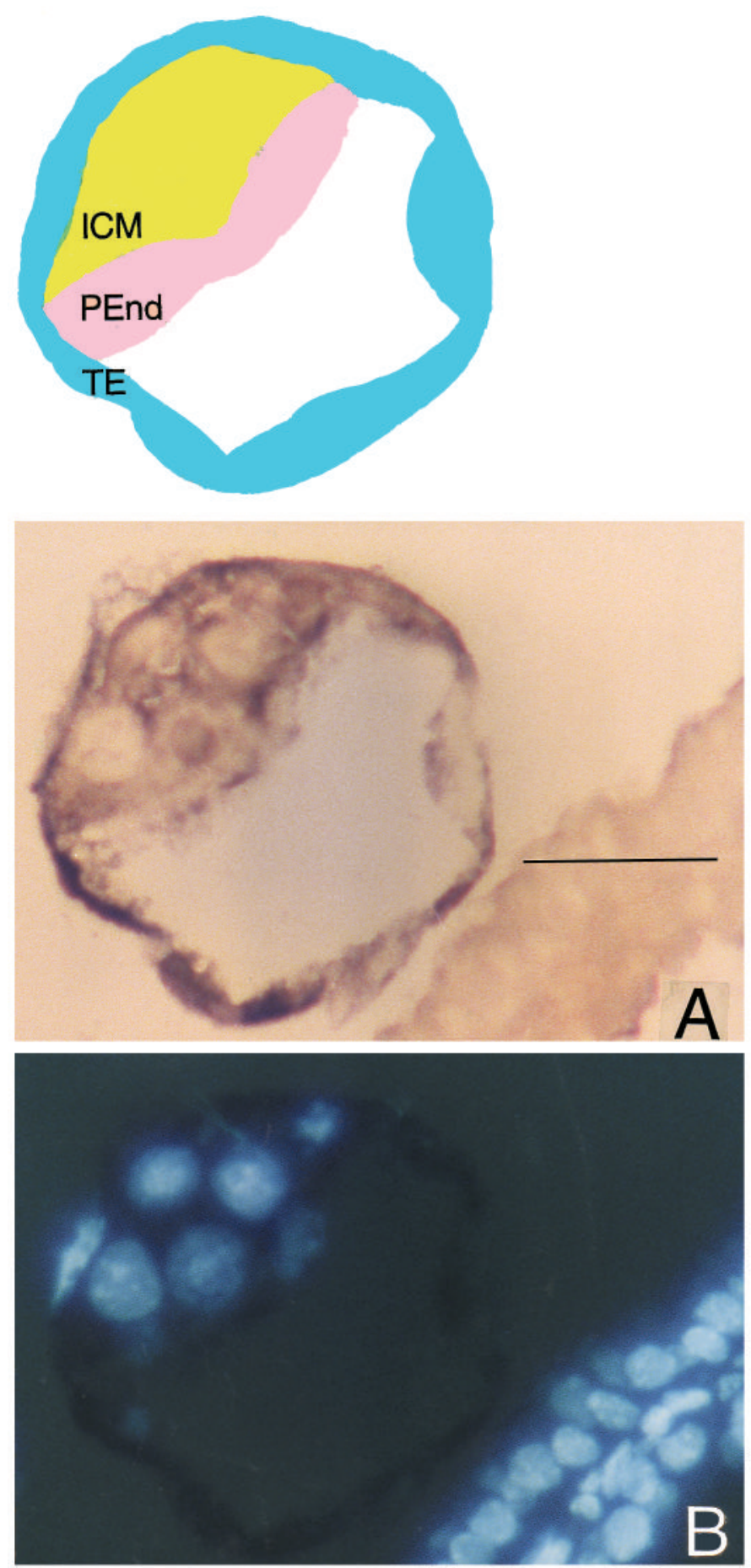
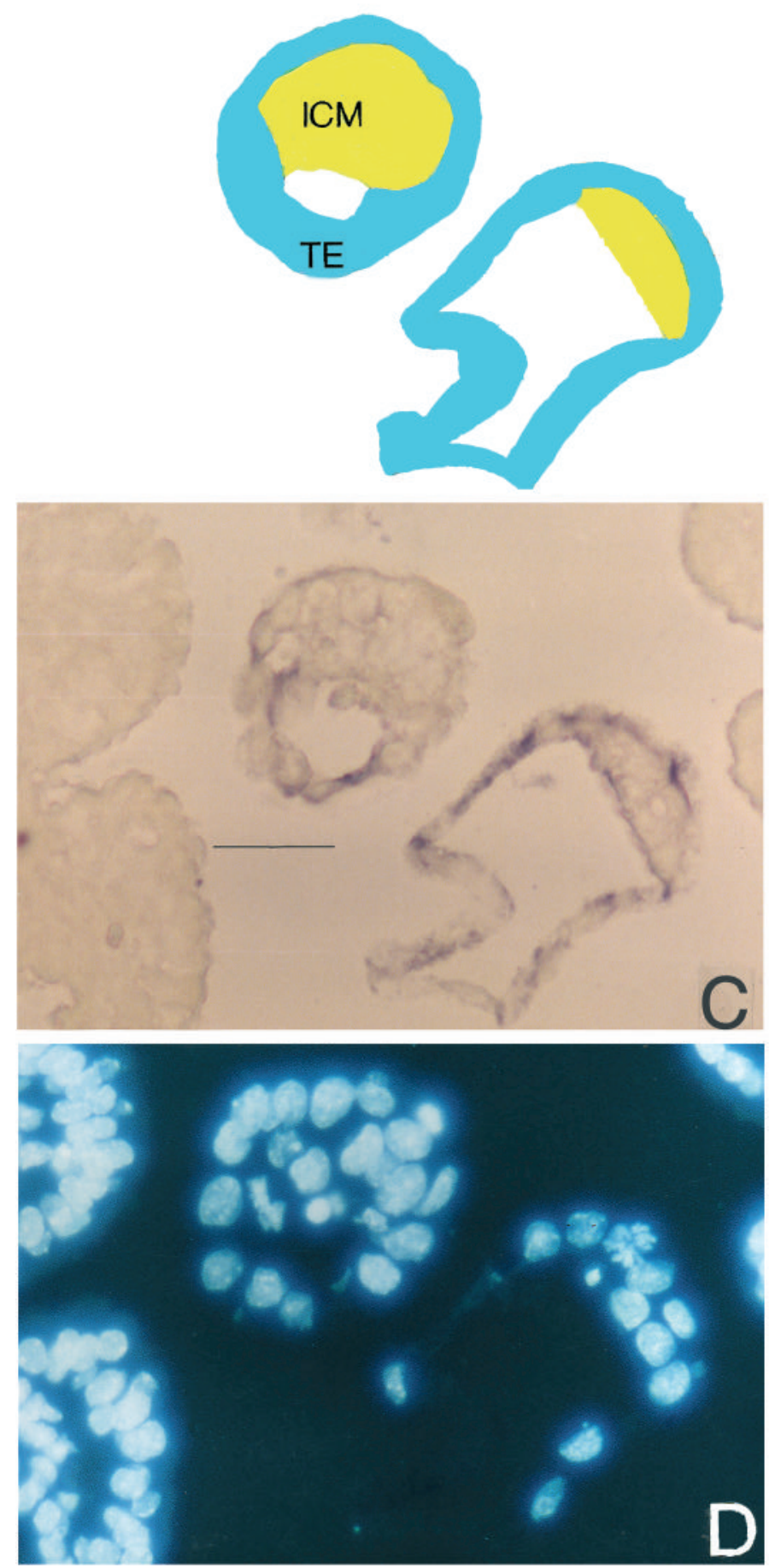

Fig. 6. mRNA transcripts for receptors for FGF are expressed in every cell of the mouse blastocyst. 3.5 day p.c. blastocysts were flushed from the uterus and then reinjected into an oviduct for stabilization. Oviducts were fixed, and mRNA for FGFR-4 (A) or FGFR-3 (C) was detected by in situ hybridization using complementary cRNA-digoxigenin and alkaline phosphatase chemistry. Micrographs in B and D are of the same sections as A and B, respectively, stained with Hoechst 33258 to show nuclei. ICM (yellow), inner cell mass; TE (blue), trophectoderm; PEnd (pink), primitive endoderm. The bars in A and B indicate $50 \mu \mathrm{m}$.

The FGF-4 gene promoter contains a response element for the octamer binding factor. Oct-4 mRNA is expressed in mouse oocytes and blastocysts and in human oocytes and blastocysts (Curatola and Basilico, 1990; Scholer et al., 1989a,b; Scholer, 1991; Abdel-Rahman et al., unpublished data), suggesting a role for Oct-4 in activating the transcription of FGF-
4 in the earliest stages of mouse and human embryos. In the preimplantation stages of mouse development, Oct-4 and FGF4 have temporally and spatially overlapping expression patterns (this paper; Niswander and Martin, 1992; Scholer, 1991) but, in postimplantation mouse embryos, FGF-4 and Oct-4 are expressed in distinct regions as well as in overlap- 
ping regions (Niswander and Martin, 1992; Rosner et al., 1990). This suggests that Oct-4, a trans-activating factor, is neither necessary nor sufficient for FGF-4 expression but, in preimplantation mammalian embryos, it may be an important regulator of FGF-4 expression.

Unlike FGF-1 and FGF-2, but like the other FGFs, FGF-4 has a leader sequence, is secreted and may have paracrine effects (Curatola and Basilico, 1990; Delli-Bovi et al., 1987). Isolated, cultured ICMs responded to FGF-4 with an increase in the outgrowth of medium-sized cells that morphologically resembled parietal endoderm cells. Because ICMs were isolated late in blastocyst development, they were not capable of producing trophectoderm cells, which might resemble parietal endoderm (Hogan and Tilly; 1978; Handyside, 1978). In a separate study, we have definitively identified these cells as parietal endoderm by their expression of laminin, SPARC, keratin, vimentin and tissue plasminogen activator (Behrendtsen et al., unpublished data). This suggests a paracrine or autocrine role for FGF-4 produced in the ICM. In the mouse limb bud, FGF-4 of the apical ectodermal ridge may mediate a paracrine induction of both progress zone mesenchyme and the zone of polarizing activity (Niswander and Martin, 1993a,b; Vogel and Tickle, 1993). These data suggest that FGF-4 produced by the ICM may influence the behavior of both the parietal endoderm and the delaminating primitive endoderm.

In mouse the primitive endoderm does not contribute to the embryo proper, but is crucial for formation of the extraembryonic endoderm of the visceral and parietal yolk sacs (Gardner and Rossant, 1979; Cockroft and Gardner, 1987). Descendants of the primitive endoderm in mouse are apposite to primitive ectoderm in the gastrulation-stage mouse and may act like the endoderm, which is crucial in mesoderm induction at gastrulation in frog and chick (Slack, 1991). These data suggest that the formation of extraembryonic endoderm in mouse is likely to be important in later induction of mouse mesoderm as well. In frog, the FGF-4/-6 homologue (XeFGF) is a maternal mRNA transcript that may be important in mesoderm induction (Isaacs et al., 1992). FGF-4 induces mesoderm in explanted frog animal caps (Paterno et al., 1989). The induction of mesoderm correlates with the expression of brachyury (Wilkinson et al., 1990), and the mRNA for brachyury is first expressed after the expression of both FGF3 and FGF-4 at day 6 p.c., but before overt mesoderm differentiation during gastrulation at day 7.0 p.c. (Hogan et al., 1986). Because fate maps of mouse, frog and chick are similar at gastrulation (Lawson et al., 1991), some common mechanisms may be involved in pregastrulation development in the three species. ICM-derived FGF-4 may contribute directly to the formation of primitive endoderm and parietal endoderm or indirectly to the formation of mesoderm.

We found that mouse embryos cultured from the 2-cell through the blastocyst stage in the presence of recombinant FGF-4 did not increase their cell number compared with embryos grown in medium alone. Other ligands such as IGFs, insulin and TGF- $\alpha$ which give signals through protein tyrosine kinase receptors, affect early embryos under similar conditions (Rappolee et al., 1992; Dardik and Schultz, 1991). This suggests that FGF-4 may not react mitogenically with both high-and low-affinity receptors on the apical surface of the trophectoderm. However, FGFR-4 mRNA and syndecan mRNA are co-expressed with Rex-1 mRNA in both trophectoderm and ICM, and FGFR-3 mRNA is present in trophectoderm (Rappolee et al., unpublished data). The lack of response of trophectoderm may be due to expression of FGF receptors only on the basal surface of the trophectoderm or to a nonmitogenic response by the trophectoderm.

Because FGF-4 increases the number of parietal endodermlike cells growing out from cultured ICMs, and because delaminating endoderm expresses both high-and low-affinity FGF receptors, then ICM, primitive endoderm or parietal endoderm may be influenced by ICM-derived FGF-4. No change in growth rate of the ICM has been observed in culture with FGF-4. This could indicate either that FGF receptors in the ICM are saturated with endogenous FGF-4 or that the growth of ICM cells is not significantly affected by FGF. However, several lines of evidence suggest that ICM-derived FGF-4 acts upon the ICM. Mutant mouse blastocysts with a targeted null mutation in the FGF-4 gene give rise to a high number of empty decidua and blastocyst outgrowths fail to produce an increase of ICM cells during culture (M. Goldfarb, personal communication). In our study, the number of cells growing out from normal cultured ICM increased rapidly, suggesting a rapid response to exogenous FGF-4. All cells in the blastocyst (ICM, primitive endoderm or trophectoderm) express mRNA transcripts for both receptors for FGF-4, FGFR-4 and FGFR-3. All cells in the preimplantation embryos also express protein for FGFR-4 (Rappolee et al., unpublished data). Interestingly, in the time between implantation and gastrulation, when parietal endoderm arises, the only cell type not expressing FGFR-3 or FGFR-4 is parietal endoderm (Rappolee et al., unpublished data). Thus, it is likely the effects of FGF-4 in the ICM outgrowth model are mediated by cells that are precursors to parietal endoderm. Undifferentiated F9 cells expressing a dominant negative FGF receptor have a slowed rate of growth (and nearly half of the stable lines die during cloning). F9 cells differentiated to parietal endoderm have a normal rate of growth when expressing the dominant negative FGF receptor (Rappolee, unpublished data). Mouse embryos expressing a dominant negative FGF receptor do not progress beyond the blastocyst stage in vitro (Rappolee and Patel, unpublished data). It has been shown that preimplantation mouse embryos cultured at low density proliferate slowly, but the growth rate can be increased by adding epidermal growth factor (Paria and Dey, 1990). Experimental evaluation of the effect of FGF-4 on the growth of isolated ICMs also required that ICMs be cultured at low density. Taken together, these data suggest that the endogenous FGF-4 influences the ICM.

We have previously found that as embryonic stem cells differentiate to endoderm they begin to secrete $92 \mathrm{kDa}$ gelatinase (Brenner et al., 1989; Adler et al., 1990; Behrendtsen et al., 1992). Plasminogen activator expression is also induced with endoderm differentiation (Marotti et al., 1982; Imada et al., 1990). ICM cells differentiating in the presence of FGF-4 increased their secretion of $92 \mathrm{kDa}$ gelatinase and tissue plasminogen activator. This strengthens the hypothesis that FGF4 produced by the ICM may regulate the secretory and behavioral phenotype of endoderm cells. $92 \mathrm{kDa}$ gelatinase has been implicated in migration and penetration of basement membranes by cells and is correlated with cell growth (Adler et al., 1990; Alexander and Werb, 1992; Behrendtsen et al., 
1992; Behrendtsen et al., unpublished data). Retinoic acid induces the expression of $92 \mathrm{kDa}$ gelatinase during the induction of F9 teratocarcinoma-derived parietal endoderm cells and in cells growing out from cultured ICMs (Adler et al., 1990; Behrendtsen et al., 1992). The morphology of the outgrowing cells, the potency of the ICM to produce endoderm but not trophectoderm, and the induction of these proteinases indicates that the outgrowing cells induced by FGF-4 are parietal endoderm.

Although cells of the vegetal half from frog embryos form endoderm when cultured without the animal cap, there is no definitive evidence that the endoderm after cortical rotation has a mesoderm-inducing default state independent of the animal cap. Similarly, mouse ICM delaminates endoderm, which requires programming to fulfill its putative roles in acquiring nutrients and inducing mesoderm. Although this study suggests a role for ICM-derived FGF-4 in programming endoderm, effects on ICM or trophectoderm are not precluded. These possibilities may be investigated by judicious ablation of ICMderived FGF-4 or of the FGF signal-receiving mechanisms in each target cell.

We thank Ole Behrendtsen for excellent technicall assistance, Yvonne Lemons and Richard Lyman for secretarial help, and Phil Iannaccone for comments on the manuscript. D. A. R. was supported by funds from NIH (National Research Service Award 5 T32 ES07106), the American Cancer Society, Illinois Division (\#93-29), and the Lucille P. Markey Charitable Trust; C.B. was supported by the NCI (CA-42568), and Z. W. was supported by the Office of Health and Environmental Research, US Department of Energy, contract DEAC03-76-SF01012, and by NIH grants HD26732 and HD23539.

\section{REFERENCES}

Adler, R. R., Brenner, C. A. and Werb, Z. (1990). Expression of extracellular matrix-degrading metalloproteinases and metalloproteinase inhibitors is developmentally regulated during endodermdifferentiation of embryonal carcinoma cells. Development 110, 211-220.

Alexander, C. and Werb, Z. (1992). Targeted disruption of the tissue inhibitor of metalloproteinases gene increases the invasive behavior of primitive mesenchymal cells derived from embryonic stem cells in vitro. J. Cell Biol. 118, 727-739.

Amaya, E., Musci, T. J. and Kirschner, M. W. (1991). Expression of a dominant negative mutant of the FGF receptor disrupts mesoderm formation in Xenopus embryos. Cell 66, 257-270.

Amaya, E., Stein, P. A., Musci, T. J. and Kirschner, M. W. (1993). FGF signalling in the early specification of mesoderm in Xenopus. Development 118, 477-487.

Basilico, C. and Moscatelli, D. (1992). The FGF family of growth factors and oncogenes. Adv. Cancer Res. 59, 115-165.

Behrendtsen, O., Alexander, C. M. and Werb, Z. (1992). Metalloproteinases mediate extracellular matrix degradation by cells from mouse blastocyst outgrowths. Development 114, 447-456.

Bellosta, P., Talarico, D., Rogers, D. and Basilico, C. (1993). Cleavage of KFGF produces a truncated molecule with increased biological activity and receptor binding affinity. J. Cell Biol. 121, 705-713.

Brenner, C. A., Adler, R. R, Rappolee, D. A., Pedersen, R. A. and Werb, Z. (1989). Genes for extracellular matrix-degrading metalloproteinases and their inhibitor, TIMP, are expressed during early mammalian development. Genes Dev. 3, 848-859.

Chapman, D. L. and Wolgemuth, D. J. (1993). Isolation of the murine cyclin B2 cDNA and characterization of the lineage and temporal specificity of expression of the B1 and B2 cyclins during oogenesis, spermatogenesis and early embryogenesis. Development 118, 229-240.

Chatot, C. L., Ziomek, C. A., Bavister, B. D., Lewis, J. L. and Torres, I. (1989). An improved culture medium supports development of random-bred 1-cell mouse embryos in vitro. J. Reprod. Fert. 86, 679-688.
Chirgwin, J. M., Przybyla, A. E., MacDonald, R. J. and Rutter, W. J. (1979). Isolation of biologically active ribonucleic acid from sources enriched in ribonuclease. Biochemistry 18, 5294-5299.

Cockroft, D. L. and Gardner, R. L. (1987). Clonal analysis of the developmental potential of 6 th and 7 th day visceral endoderm cells in the mouse. Development 101,143-145.

Conquet, F. and Brulet, P. (1990). Developmental expression of myeloid leukemia inhibitory factor gene in preimplantation blastocysts and in extraembryonic tissue of mouse embryos. Mol. Cell. Biol. 10, 3801-3805.

Curatola, A. M. and Basilico, C. (1990). Expression of the K-fgf protooncogene is controlled by $3^{\prime}$ regulatory elements which are specific for embryonal carcinoma cells. Mol. Cell. Biol. 10, 2475-2484.

Dardik, A. and Schultz, R. M. (1991). Blastocoel expansion in the preimplantation mouse embryo: stimulatory effect of TGF- $\alpha$ and EGF. Development 113, 919-930.

Delli Bovi, P., Curatola, A. M., Kern, F. G., Greco, A., Ittmann, M. and Basilico, C. (1987). An oncogene isolated by transfection of Kaposi's sarcoma DNA encodes a growth factor that is a member of the FGF family. Cell 50, 729-737.

Dickson, C. and Peters, G. (1987). Potential oncogene product related to growth factors (letter). Nature 326, 833.

Dionne, C. A., Crumley, G., Bellot, F., Kaplow, J. M., Searfoss, G., Ruta, M., Burgess, W. H., Jaye, M. and Schlessinger, J. (1990). Cloning and expression of two distinct high-affinity receptors cross-reacting with acidic and basic fibroblast growth factors. EMBO J. 9, 2685-2692.

Gardner, R. L. and Rossant, J. (1979). Investigation of the fate of 4-5 day post-coitum mouse inner cell mass cells by blastocyst injection. J. Embryol. Exp. Morph. 52, 141-152.

Gearing D. P., King, J. A. and Gough, N. M. (1988). Complete sequence of murine myeloid leukaemia inhibitory factor (LIF). Nucl. Acids Res. 16, 9857.

Glantz, S. A. (1992). Primer of Biostatistics: The Program. Version 3. 0. New York: McGraw-Hill.

Hahnel, A. C., Rappolee, D. A., Millan, J. L., Manes, T., Ziomek, C. A., Theodosiou, N. G., Werb, Z., Pedersen, R. A. and Schultz, G. A. (1990). Two alkaline phosphatase genes are expressed during early development in the mouse embryo. Development 110, 555-564.

Handyside, A. H. (1978). Time of commitment of inside cells isolated from preimplantation mouse embryos. J. Embryol. Exp. Morph. 45, 37-53.

Handyside, A. H. and Hunter, S. (1984). A rapid procedure for visualising the inner cell mass and trophectoderm nuclei of mouse blastocysts in situ using polynucleotide-specific fluorochromes. J. Exp. Zool. 231, 429-434.

Harkey, M. A., Whiteley, H. R., and Whiteley, A. H. (1992). Differential expression of the msp 130 gene among skeletal lineage cells in the sea urchin embryo: a three dimensional in situ hybridization analysis. Mech. Devl. 37, 173-184.

Hebert, J. M., Basilico, C., Goldfarb, M., Haub, O. and Martin, G. (1990) Isolation of cDNAs encoding four mouse FGF family members and characterization of their expression patterns during embryogenesis. Dev. Biol. 138, 454-463.

Herrmann, B. G., Labeit, S., Poustka, A., King, T. R. and Lehrach, H. (1990). Cloning of the T gene required in mesoderm formation in the mouse. Nature 343, 617-622.

Hogan, B. and Tilly, R. (1978). In vitro development of inner cell masses isolated immunosurgically from mouse blastocysts. II. Inner cell masses from 3. 5- to 4. 0-day p. c. blastocysts. J. Embryol. Exp. Morph. 45, 107-121.

Hogan, B., Costantini, F. and Lacy, E. (1986). Manipulating the Mouse Embryo, A Laboratory Manual. Cold Spring Harbor, NY: Cold Spring Harbor Laboratory.

Imada, S., Yamaguchi, H. and Imada, M. (1990). Differential expression of fetomodulin and tissue plasminogen activator to characterize parietal endoderm differentiation of F9 embryonal carcinoma cells. Dev. Biol. 141 426-430.

Isaacs, H. V., Tannahill, D. and Slack J. M. W. (1992). Expression of a novel FGF in the Xenopus embryo. A new candidate inducing factor for mesoderm formation and anteroposterior specification. Development 114, 711-720.

Johnson, D. E., Lu, J., Chen, H., Werner, S. and Williams, L. T. (1991). The human fibroblast growth factor receptor genes: a common structural arrangement underlies the mechanisms for generating receptor forms that differ in their third immunoglobulin domain. Mol. Cell. Biol. 11, $4627-$ 4634.

Keegan, K., Johnson, D. E., Williams, L. T. and Hayman, M. J. (1991). Isolation of an additional member of the fibroblast growth factor receptor family, FGFR-3. Proc. Natl. Acad. Sci. USA 88, 1095-1099.

Kimelman, D. and Kirschner, M. (1987). Synergistic induction of mesoderm 
by FGF and TGF- $\beta$ and the identification of an mRNA coding for FGF in the early Xenopus embryo. Cell 51, 869-877.

Kimelman, D., and Maas, A. (1992). Induction of dorsal and ventral mesoderm by ectopically expressed Xenopus basic fibroblast growth factor. Development 114, 261-269.

Klagsbrun, M. and Baird, A. (1991). A dual receptor system is required for basic fibroblast growth factor activity. Cell 67, 229-231.

Lawson, K. A., Meneses, J. J. and Pedersen, R. A. (1991). Clonal analysis of epiblast fate during germ layer information in the mouse embryo. Development 113, 891-911.

Lee, P. L., Johnson, D. E., Cousens, L. S., Fried, V. A. and Williams, L. T. (1989). Purification and complementary DNA cloning of a receptor for basic fibroblast growth factor. Science 245, 57-60.

Mansour, S. L., Goddard, J. M. and Capecchi, M. R. (1993). Mice homozygous for a targeted disruption of the proto-oncogene int- 2 have developmental defects in the tail and inner ear. Development 117, 13-28.

Marotti, K. R., Belin, D. and Strickland, S. (1982). The production of distinct forms of plasminogen activator by mouse embryonic cells. Dev. Biol. 90, 154-159.

Miyamoto, M., Naruo, K., Seko, C., Matsumoto, S., Kondo, T. and Kurokawa, T. (1993). Molecular cloning of a novel cytokine cDNA encoding the ninth member of the fibroblast growth factor family, which has a unique secretion property. Mol. Cell. Biol. 13, 4251-4259.

Murray, R., Lee, F. and Chiu, C. P. (1990). The genes for leukemia inhibitory factor and interleukin-6 are expressed in mouse blastocysts prior to the onset of hemopoiesis. Mol. Cell. Biol. 10, 4953-4956.

Niswander, L. and Martin, G. R. (1992). Fgf-4 expression during gastrulation, myogenesis, limb and tooth development in the mouse Development 114, 755-768

Niswander, L. and Martin, G. R. (1993a). FGF-4 and BMP-2 have opposite effects on limb growth. Nature 361, 68-71.

Niswander, L. and Martin, G. R. (1993b). FGF-4 regulates expression of Evx-1 in the developing mouse limb. Development 119, 287-294.

Orr-Urtreger, A., Givol, D., Yayon, A., Yarden, Y. and Lonai, P. (1991). Developmental expression of two murine fibroblast growth factor receptors, flg and bek. Development 113, 1419-1434.

Paria, B. C. and Dey, S. K. (1990). Preimplantation embryo development in vitro: cooperative interactions among embryos and role of growth factors. Proc. Natl. Acad. Sci. USA 87, 4756-4760.

Partanen, J., Makela, T. P., Eerola, E., Korhonen, J., Hirhoven, H., Claesson-Welsh, L. and Alitalo, K. (1991). FGFR-4, a novel acidic fibroblast growth factor receptor with a distinct expression pattern. EMBO J. 10, 1347-1354

Partanen, J., Vainikka, S., Korhonen, J., Armstrong, E. and Alitalo, K. (1992). Diverse receptors for fibroblast growth factors. Prog. Growth Factor Res. 4, 69-83.

Paterno, G. D., Gillespie, L. L., Dixon, M. S., Slack, J. M. W. and Heath, J. K. (1989). Mesoderm-inducing properties of INT-2 and kFGF: two oncogene-encoded growth factors related to FGF. Development 106, 79-83.

Rappolee, D. A. and Werb, Z. (1994). The role of growth factors in mammalian pregastrulation development. In Growth Factors in Early Development, Greenwich, Conn.: JAI Press. In press.

Rappolee, D. A., Brenner, C. A., Schultz, R., Mark, D. and Werb, Z. (1988) Developmental expression of PDGF, TGF- $\alpha$, and TGF- $\beta$ genes in preimplantation mouse embryos. Science 241, 1823-1825.

Rappolee, D. A., Wang A., Mark D. and Werb Z. (1989). Novel method for studying mRNA phenotypes in single or small numbers of cells. J. Cell. Biochem. 39, 1-11.

Rappolee, D. A., Sturm, K. S., Behrendtsen, O., Schultz, G. A., Pedersen, R. A. and Werb, Z. (1992). Insulin-like growth factor II acts through an endogenous growth pathway regulated by imprinting in early mouse embryos. Genes Dev. 6, 939-952.
Robertson, E. J. (ed.) (1987). Teratocarcinomas and Embryonic Stem Cells: A Practical Approach. Oxford: IRL Press.

Rosner, M. H., Vigano, M. A., Ozato, K., Timmons, P. M., Poirier, F., Rigby, P. W. J. and Staudt, L. M. (1990). A POU-domain transcription factor in early stem cells and germ cells of the mammalian embryo. Nature 345, 686-692.

Ruiz i Altaba, A. and Melton, D. A. (1989). Interaction between peptide growth factors and homeobox genes in the establishment of antero-posterior polarity in frog embryos. Nature 341, 33-38.

Scholer, H. R. (1991). Octamania: the POU factors in murine development. Trends Genet. 7, 323-329.

Scholer, H. R., Hatzopoulos, A. K., Balling, R., Suzuki, N. and Gruss, P. (1989a). A family of octamer-specific proteins present during mouse embryogenesis: evidence for germline-specific expression of an Oct factor EMBO J. 8, 2543-2550.

Scholer, H. R., Balling, R., Hatzopoulos, A. K., Suzuki, N. and Gruss, P. (1989b). Octamer binding proteins confer transcriptional activity in early mouse embryogenesis. EMBO J. 8, 2551-2557.

Slack, J. M. W. (1991). From Egg to Embryo: Regional Specification in Early Development, ed. 2, Cambridge: Cambridge University Press.

Solter, D. and Knowles, B. B. (1975). Immunosurgery of mouse blastocyst. Proc. Natl. Acad. Sci. USA 72, 5099-5102.

Solter, D., Shevinsky, L., Knowles, B. B. and Strickland, S. (1979). The induction of antigenic changes in a teratocarcinoma stem cell line (F9) by retinoic acid. Dev. Biol. 70, 515-521.

Spindle, A. (1980). An improved culture medium for mouse blastocysts. In Vitro 16, 669-674.

Strickland, S., Smith, K. K. and Marotti, K. R. (1980). Hormonal induction of differentiation in teratocarcinoma stem cells: generation of parietal endoderm by retinoic acid and dibutyryl cAMP. Cell 21, 347-355.

Sutherland, A. E., Sanderson, R. D., Mayes, M., Seibert, M., Calarco, P. G., Bernfield, M., and Damsky, C. H. (1991). Expression of syndecan, a putative low affinity fibroblast growth factor receptor, in the early mouse embryo. Development 113, 339-351.

Tam, P. P. L. and Beddington, R. S. P. (1987). The formation of mesodermal tissues in the mouse embryo during gastrulation and early organogenesis. Development 99, 109-126.

Tanaka, A., Miyamoto, K., Minamino, N., Takeda, M., Sato, B., Matsuo, H. and Matsumoto, K. (1992). Cloning and characterization of an androgen-induced growth factor essential for the androgen-dependent growth of mouse mammary carcinoma cells. Proc. Natl. Acad. Sci. USA 89, 8928-8932.

Unemori, E. N. and Werb, Z. (1988). Collagenase expression and endogenous activation in rabbit synovial fibroblasts stimulated by the calcium ionophore A23187. J. Biol. Chem. 263, 16252-16259.

Velcich, A., Delli-Bovi, P., Mansukhani, A., Ziff, E. B. and Basilico, C. (1989). Expression of the K-fgf protooncogene is repressed during differentiation of F9 cells. Oncogene Res. 5, 31-37.

Vogel, A. and Tickle, C. (1993). FGF-4 maintains polarizing activity of posterior limb bud cells in vivo and in vitro. Development 119, 199-206.

Wilkinson, D. G., Peters, G., Dickson, C. and McMahon, A. P. (1988). Expression of the FGF-related proto-oncogene int-2 during gastrulation and neurulation in the mouse. EMBO J. 7, 691-695.

Wilkinson, D. G., Bhatt, S. and Herrmann, B. G. (1990). Expression pattern of the mouse $\mathrm{T}$ gene and its role in mesoderm formation. Nature 343, 657659

Yamaguchi, T. P., Conlon, R. A., and Rossant, J. (1992). Expression of the fibroblast growth factor receptor FGFR-1/flg during gastrulation and segmentation in the mouse embryo. Dev. Biol. 152, 75-88

(Accepted 20 April 1994) 